\title{
The first Eocene rodents from the Pacific Northwest, USA
}

\author{
Joshua X. Samuels and William W. Korth
}

\begin{abstract}
The Oligocene and Miocene faunas of the John Day Basin are diverse and very well-studied, including a large number of small mammal species. Though Eocene floras from Oregon are well-known, Eocene faunas include relatively few taxa from only two described localities in the Clarno area. The first Eocene rodents from the John Day Basin also include the first ischyromyids from the Pacific Northwest. Several rodent incisors were recovered from the Hancock Mammal Quarry at Clarno, representing the first rodent specimens known from the Clarno Formation. The Hancock Mammal Quarry lies between tuffs dated 42.7 and $39.22 \mathrm{Ma}$, meaning these rodents are latest Uintan or earliest Duchesnean in age. Several ischyromyids are also described from the Big Basin Member of the John Day Formation. From a Duchesnean locality between tuffs dated 39.22 and $38.4 \mathrm{Ma}$ a single tooth of Pseudotomus was recovered, which is as large as any known ischyromyid. Another Big Basin Member site yielded a new genus and species of ischyromyid. That site lies above an ash dated 36.21 Ma and biostratigraphy confirms a Chadronian age. These rodents help fill important gaps in the fossil record of the John Day Basin and will facilitate comparisons with other Eocene sites in North America and Asia.
\end{abstract}

Joshua X. Samuels. East Tennessee State University, Department of Geosciences and Museum of Natural History, Johnson City, Tennessee, 37614, samuelsjx@etsu.edu

William W. Korth. Rochester Institute of Vertebrate Paleontology, 265 Carling Road, Rochester, New York 14610,wwkorth@frontiernet.net

Keywords: Rodentia; Ischyromyidae; new genus; new species; Clarno Formation; John Day Formation

Submission: 30 August 2016 Acceptance: 19 May 2017

http://zoobank.org/AE5A939F-D060-485E-BBA4-ED129D1A034F

Samuels, Joshua X. and Korth, William W. 2017. The first Eocene rodents from the Pacific Northwest, USA. Palaeontologia

Electronica 20.2.24A: 1-17

palaeo-electronica.org/content/2017/1874-eocene-rodents-from-oregon

Copyright: @ May 2017 Society of Vertebrate Paleontology. This is an open access article distributed under the terms of the Creative Commons Attribution License, which permits unrestricted use, distribution, and reproduction in any medium, provided the original author and source are credited.

creativecommons.org/licenses/by/4.0/ 


\section{INTRODUCTION}

The John Day Basin of Oregon is known for preserving one of the best records of Cenozoic faunal and floral change in the world. About 50 million years of time are recorded in a nearly continuous sequence of rocks in the region, and hundreds of localities have yielded fossils ranging from the Middle Eocene to Late Miocene. The John Day Basin has been studied for over 150 years, but while knowledge of the region's past is extensive, there are definite gaps. Faunas from the Oligocene and Miocene are very well-studied and document incredible mammal diversity, but the faunas from older Eocene strata are less well-known. Only two Eocene localities from the John Day Basin include documented mammal faunas, the Clarno Nut Beds and the Hancock Mammal Quarry (Hanson, 1989, 1996; Fremd, 2010). In contrast, there are many Eocene paleobotanical sites in the John Day Basin (Chaney, 1924, 1927, 1948; Manchester, 1990, 1994, 2000; Meyer and Manchester, 1997, Wheeler and Manchester, 2002, 2006; Manchester and Mclntosh, 2007; Dillhoff et al., 2009), which provide a detailed picture of changes in climate and habitats from the Middle Eocene to the Oligocene.

Both of the described Eocene faunas of Oregon come from the Clarno Formation, and neither is particularly diverse. The mid-Uintan age Clarno Nut Beds represent the oldest Cenozoic vertebrate fauna from the Pacific Northwest (Robinson et al., 2004; Fremd, 2010). Vertebrate fossils are rare and fragmentary from the Clarno Nut beds (Stirton, 1944; Hanson, 1989, 1996; Fremd, 2010); specimens from the fauna are mainly from the dwarf brontothere, Xylotitan (Mihlbachler and Samuels, 2016), along with a few specimens of Orohippus, Hyrachyus, Patriofelis, Hadrianus, and a crocodile (Stirton, 1944; Hanson, 1996). The second vertebrate locality from Clarno, the Hancock Mammal Quarry, represents the only vertebrate quarry deposit in the region (Pratt, 1988; Hanson, 1996; Fremd, 2010). The majority of specimens from the quarry are from a few common large mammals, primarily Eubrontotherium, Zaisanamynodon, and Teletaceras, along with rarer specimens of Plesiocolopirus and Diplobunops (Hanson, 1989, 1996; Lucas, 2006; Mihlbachler, 2007; Emery et al., 2016). Hanson (1996) indicated that small mammals were uncommon in the quarry and that only a few rodent incisors had been recovered from the site. However, none of these specimens have ever been described or figured. To date, the smallest mammals described from the Hancock Mammal
Quarry are the horses Epihippus and Haplohippus (Hanson, 1996).

Overlying the Clarno Formation is the John Day Formation, the lower part of which is also Eocene in age. Abundant late Eocene and early Oligocene plant fossils are known from the Big Basin Member of the John Day Formation, but vertebrate fossils tend to be rare and highly fragmentary. Only two vertebrates have been described from Big Basin Member strata, a mudminnow, Novumbra oregonensis (Cavender, 1969), and a newt, Taricha lindoei (Naylor, 1979). The only figured mammal specimens from Big Basin strata are a partial entelodont jaw (Coleman, 1949) and fragments of an unidentified bat (Brown, 1959). All of those described and figured vertebrates were collected from lacustrine deposits associated with the Bridge Creek Flora, which is considered earliest Oligocene in age. Merriam (1901) and Merriam and Sinclair (1907) also noted the presence of fragments of horses, rhinos, and entelodonts from heavily-weathered early Oligocene claystones that are now considered the upper portion of the Big Basin Member strata.

Faunal lists in a number of subsequent studies have included mammal species from the Big Basin Member (Fremd et al., 1994; Albright et al., 2008; Fremd, 2010). However, no rodents are among the taxa listed, and none of the other Big Basin mammals have ever been described. Among the fossils collected from Big Basin Member strata over the last century there are a few Eocene rodent specimens. Though fragmentary, those rodents are important for understanding the composition of late Eocene communities and the origin of the wellknown Oligocene rodent faunas of Oregon.

\section{MATERIALS AND METHODS}

The John Day Basin includes hundreds of fossil bearing localities scattered across central and eastern Oregon. Despite considerable collecting effort over more than a century, only a handful of rodent specimens have ever been collected from Eocene strata in Oregon. The specimens described here come from three Eocene sites, one site (Hancock Mammal Quarry) within the Clarno Unit of John Day Fossil Beds National Monument, another locality (Whitecap Knoll) just outside the Clarno Unit, and a third site (Lost Creek) near the Crooked River (Figure 1).

Dental terminology follows that of Wood and Wilson (1936) and Wood (1962). Upper teeth are designated by capital letters, lower teeth by lowercase letters (e.g., M1, m1). Measurements were 


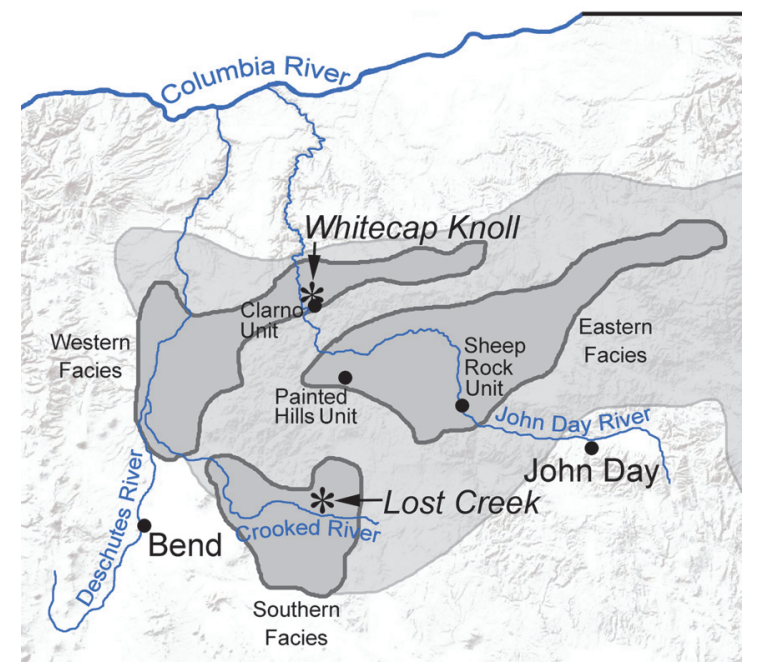

FIGURE 1. Map showing the distribution of the Clarno and John Day Formations in central and eastern Oregon, as well as the location of the three units of John Day Fossil Beds National Monument and other localities mentioned here. The Clarno Formation is represented by light shaded area, while the eastern, western, and southern facies of the John Day Formation are represented in darker shading. Map modified from Robinson et al. (1984) and Albright et al. (2008).

made using Mitutoyo Absolute digital calipers to the nearest $0.01 \mathrm{~mm}$. Dimensions of all teeth were measured at the occlusal surface, as described by Wood (1962). Abbreviations are as follows: JDNM, John Day Fossil Beds National Monument (locality designation); JODA, John Day Fossil Beds National Monument (museum collection); UC, University of California Berkeley (locality designation); UCMP, University of California Museum of Paleontology; UO, University of Oregon (locality designation); UOMNH, University of Oregon Museum of Natural and Cultural History.

\section{GEOLOGICAL SETTING}

The specimens described here originate from the top of the Clarno Formation and lower part of the John Day Formation (Figure 2). Spanning most of the Eocene (ranging from about 54 to $39 \mathrm{Ma}$ ) and distributed widely throughout central and eastern Oregon, the Clarno Formation consists of diverse volcanic rocks and volcaniclastic sedimentary rocks (Bestland et al., 1999; Dillhoff et al., 2009; McClaughry et al., 2009) (Figures 1, 2). Those lithologically heterogeneous and laterally discontinuous rocks formed within a low elevation extensional basin or series of basins (White and Robinson, 1992; Dillhoff et al., 2009). The Clarno

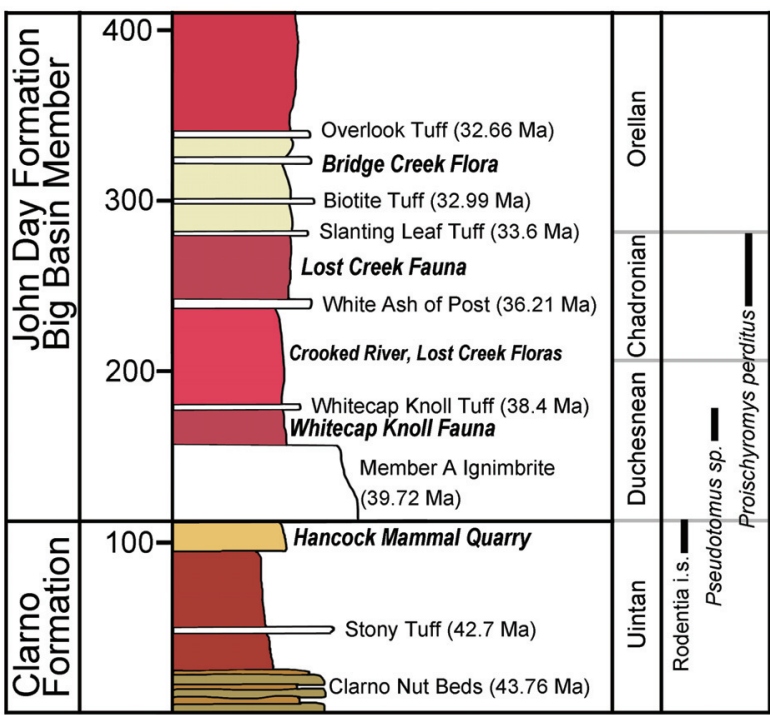

FIGURE 2. Composite stratigraphic column of the upper portion of the Clarno Formation and lower portion of the John Day Formation with stratigraphic ranges of Eocene rodents from Oregon. Composite stratigraphy based on Bestland and Retallack (1994), Bestland et al. (1999), Retallack et al. (2000), and Fremd (2010). Radiometric dates also derived from those sources, along with Manchester (2000) and Manchester and Mclntosh (2007).

volcanic rocks are interpreted as being sourced from an arc of volcanoes formed by 'flat slab' subduction beneath western North America, from the Late Cretaceous through the Middle Eocene (Noblett, 1981; White and Robinson, 1992). A number of andesitic stratocones produced basalt and andesite flows, as well as the characteristic Clarno Formation laharic breccias (White and Robinson, 1992; Dillhoff et al., 2009).

The Clarno Unit of John Day Fossil Beds National Monument (Figure 2) and surrounding area include exposures of both the Clarno Formation and the lower part of the John Day Formation. A geologic and stratigraphic framework for the deposits in that area was developed by Hanson (1996) and Bestland et al. (1999). While some debate exists over how the deposits at Clarno formed, we follow the nomenclature and radiometric dates provided by Bestland et al. (1999) (Figure 2). Above the well-known Clarno Nut Beds (Manchester, 1994; Wheeler and Manchester, 2002) on Red Hill are deeply weathered red and lavender claystone paleosols units, including a stony tuff bed dated 42.7 +/- $0.3 \mathrm{Ma}$ (Bestland and Retallack, 1994a; Bestland et al., 1999). Above the claystone of Red Hill are tan siltstones and cobble conglomerate units that also occur at the Hancock Mammal 
Quarry (Bestland et al., 1999). The quarry itself is located within those siltstones near the top of the Clarno Formation, not far (about $5 \mathrm{~m}$ ) below the unconformable contact with the John Day Formation (Bestland et al., 1999).

The complex series of strata from the John Day Formation are approximately $1000 \mathrm{~m}$ thick and consist primarily of volcaniclastic sedimentary rocks and airfall tuffs (Fisher and Rensberger, 1972; Robinson et al., 1984; Bestland and Retallack, 1994b; Retallack et al., 2000; Albright et al., 2008; McClaughry et al., 2009). Distinctive lithologies of strata throughout the sequence and a number of conspicuous marker units have allowed exposures to be correlated over great distances (Albright et al., 2008).

The John Day Formation is known from three distinct facies found in central and eastern Oregon (Figure 1; Robinson et al., 1984; Albright et al., 2008). John Day Formation stratigraphy has been studied extensively. Merriam (1901) divided it into three divisions (lower, middle, and upper) primarily based on color. Lower, middle, and upper members were also defined by Hay (1963) based on the presence of the widespread Picture Gorge Ignimbrite, his middle member. Fisher and Rensberger (1972) thoroughly studied the eastern facies and divided it into four formal members: Big Basin, Turtle Cove, Kimberly, and Haystack Valley. Fremd et al. (1994), Hunt and Stepleton (2004), and most recently Albright et al. (2008) further refined and subdivided the well-studied eastern facies, producing a detailed litho- and chronstratigraphy of the John Day Formation with radioisotopic and paleomagnetic calibration. The currently recognized eastern facies of the John Day Formation includes seven members spanning from the middle Eocene to early Miocene, about 39 to $18 \mathrm{Ma}$ (Hunt and Stepleton, 2004; Albright et al., 2008).

The western facies, including deposits in the Clarno vicinity, are less well-studied and were informally divided into members A through I (Peck, 1964; Swanson and Robinson, 1968; Swanson, 1969; Robinson, 1975). Recent studies by Retallack et al. (1996) and Bestland et al. (1999) chose to describe the western facies strata using both the informal members A through I of Peck (1964) and the formal members of Fisher and Rensberger (1972), specifically referring to the lower part of the John Day Formation near Clarno as Big Basin Member strata. The southern facies have received the least study, but show broad scale lithological similarities to strata in the eastern and western facies. In all three facies the lower part of the John
Day Formation consists of red and yellow tuffaceous claystones (Fisher and Rensberger, 1972; Meyer and Manchester, 1997; Fremd, 2010). As such, we refer to these strata as the Big Basin Member in each of the three facies (Figure 2).

Many tuffs have been radioisotopically dated from the John Day Formation, using ${ }^{40} \mathrm{Ar} / 39 \mathrm{Ar}$ single-crystal laser-fusion dating of sanidine by C.C. Swisher III (Swisher, 1992; Bestland and Retallack, 1994b; Bestland et al., 1999; Manchester, 2000; Manchester and Mclntosh, 2007; Albright et al., 2008). Among these, the most relevant to this study are the following: Member A ash-flow tuff, Whitecap Knoll tuff, and White Ash of Post. The base of the John Day Formation in much of central Oregon is marked by the Member A ash-flow tuff (Peck, 1964; Robinson, 1975), which has been ${ }^{40} \mathrm{Ar} /{ }^{39} \mathrm{Ar}$ dated from both the Clarno and Painted Hills areas, with dates of $39.22 \pm 0.03 \mathrm{Ma}$ and $39.72 \pm 0.03$ Ma respectively (Bestland and Retallack, 1994a, 1994b; Bestland et al., 1999; Retallack et al., 2000; McClaughry et al., 2009). Whitecap Knoll, near Clarno, is so named because it is capped by an indurated white tuff (Manchester, 2000). A diverse flora has been described from shale units below the Whitecap Knoll tuff; that flora is the oldest known from the John Day Formation and provides important evidence of floral changes in the middle and late Eocene of Oregon (Manchester, 2000). The Whitecap Knoll tuff has been ${ }^{40} \mathrm{Ar} /{ }^{39} \mathrm{Ar}$ dated at $38.4 \pm 0.7 \mathrm{Ma}$ (Manchester, 2000). In the area north of the Crooked River near the town of Post is a fairly widely distributed white tuff unit, which Manchester and Mclntosh (2007) referred to as the White Ash of Post. That tuff was ${ }^{40} \mathrm{Ar} /{ }^{39} \mathrm{Ar}$ dated from sanidine, yielding an age of $36.21 \pm 0.26 \mathrm{Ma}$ (Manchester and Mclntosh, 2007). Diverse paleobotanical remains are common in strata below the White Ash of Post (Meyer and Manchester, 1997; Wheeler and Manchester, 2006; Manchester and McIntosh, 2007); those remains include fossil leaves, petrified wood, and silicified fruits and seeds. Rare vertebrate fossils have also been found eroding out of dark red claystone units stratigraphically higher than the White Ash of Post, at a site referred to here as Lost Creek.

Except for the Arikareean and Hemingfordian land mammal ages, the Eocene through Miocene biostratigraphy of Oregon has not been studied in detail (Albright et al., 2008; Hunt and Stepleton, 2004). In fact, no faunas from the Duchesnean, Chadronian, or Orellan have ever been described from the Pacific Northwest. Given the boundaries 
to dispersal between Oregon and the well-studied Great Plains faunas, strong concordance between contemporaneous faunas is not necessarily expected. Both of the Clarno Formation vertebrate sites have well-constrained ages based on radiometric dates, but referring either to a NALMA is problematic. The Clarno Nut Beds are mid-Uintan (Ui2) age, but show little faunal similarity to contemporaneous sites (Robinson et al., 2004). Similarly, the late Uintan (Ui3) or earliest Duchesnean age Hancock Mammal Quarry shares taxa considered characteristic of multiple land mammal ages (Robinson et al., 2004). Interestingly, both of the previously described Eocene faunas from Clarno have distinct Asian affinities, sharing taxa like Teletaceras, Zaisanamynodon, and Plesiocolopirus with similar age faunas in Asia (Radinsky, 1963; Lucas, 1992; Hanson, 1996; Lucas, 2006; Mihlbachler, 2007; Mihlbachler and Samuels, 2016).

\section{SYSTEMATIC PALEONTOLOGY}

\section{Order RODENTIA Bowdich, 1821 \\ Rodentia incertae sedis}

(Figure 3)

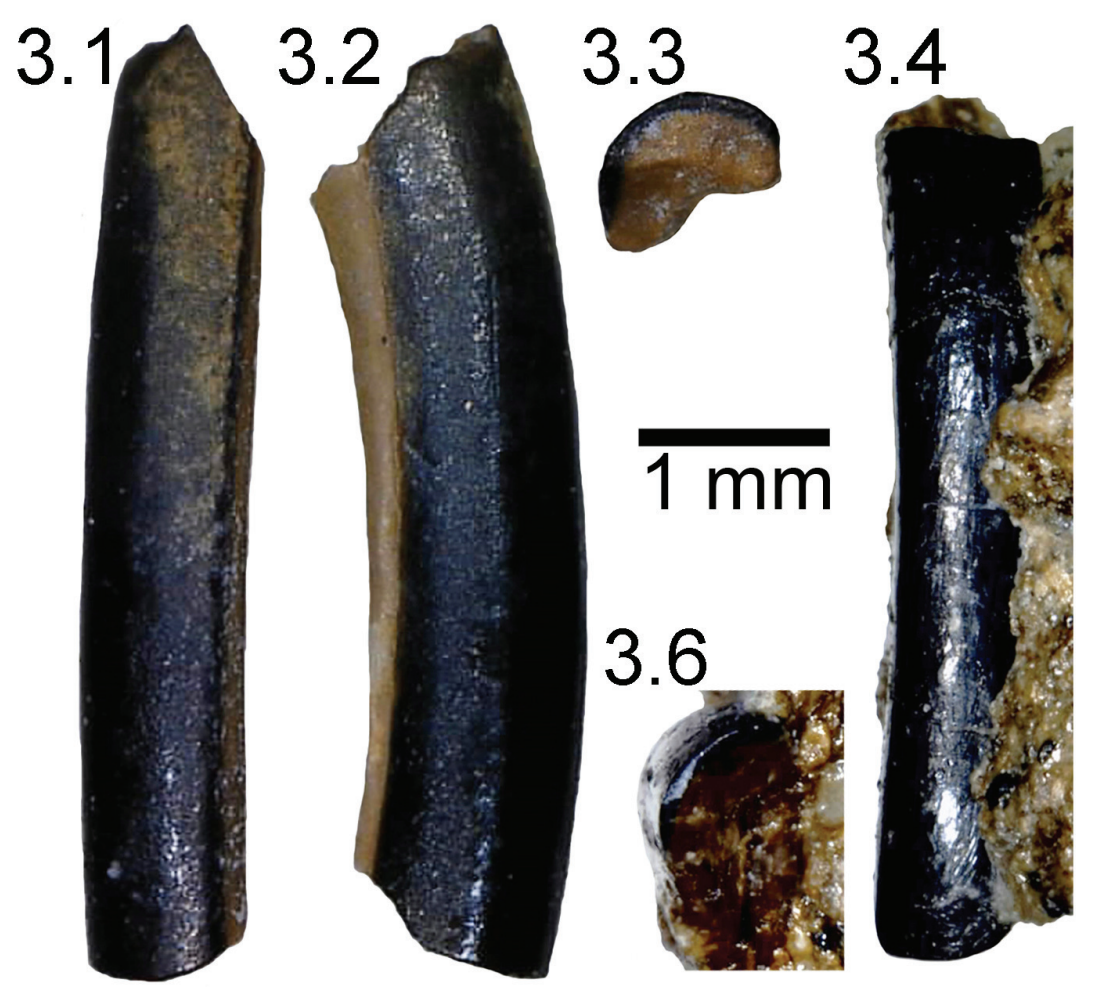

Referred specimens. JODA 16822, UOMNH F28304, UOMNH F-28307, incisor fragments.

Occurrence. JDNM-13 (UC V75203, UO 2473), Hancock Mammal Quarry, Wheeler County, Oregon, Clarno Formation.

Age. Late middle Eocene (either latest Uintan or Duchesnean NALMA), bracketed between Stony Tuff dated $42.7 \pm 0.3 \mathrm{Ma}$ (Bestland et al., 1999) and Member A Ignimbrite dated $39.22 \pm 0.03 \mathrm{Ma}$ (Bestland et al., 1999).

Measurements. UOMNH F-28304: anteroposterior length $=1.73 \mathrm{~mm}$, transverse width $=0.87 \mathrm{~mm}$; blade (wear surface) length $2.67 \mathrm{~mm}$; JODA 16822: transverse width $=0.91 \mathrm{~mm}$, blade (wear surface) length $=0.69 \mathrm{~mm}$.

Description. Both UOMNH F-28304 and F-28307 are partially imbedded in matrix, preventing observation of some details of their structure, while the posteromedial portion of the incisor is broken in JODA 16822. In UOMNH F-28304, the incisor is oval in cross-section and approximately twice as long anteroposteriorly as it is wide. In JODA 16822, the preserved portion does suggest a similar overall shape to UOMNH F-28304. The anterior and lateral surfaces of the incisors are rounded, while the

FIGURE 3. Rodentia incisor fragments from the Clarno Formation, Oregon. JODA 16822, 3.1. anterior view, 3.2. lateral view, 3.3. distal view. UOMNH F-28304, 3.4. anterior view, 3.5. lateral view, 3.6. distal view. Scale bar equals 1 $\mathrm{mm}$. 
anteromedial edge is somewhat flattened. The enamel in both UOMNH F-28304 and JODA 16822 is relatively thick and has a slightly rugose texture, though it lacks grooves or other ornamentation. In UOMNH F-28304, the anterior surface and about $1 / 3$ of the lateral surface of the incisor is covered in enamel.

Remarks. These are the first described rodent specimens from the Clarno Formation. and the oldest rodents known from the Pacific Northwest. Though fragmentary, these specimens are also significant because they are by far the smallest vertebrates ever noted from the Hancock Mammal Quarry. The previous smallest vertebrate from the site was the equid Epihippus (Hanson, 1996). JODA 16822 was collected by screen-washing sediments, specifically the spoils-piles, from earlier excavations at the site. The presence of these very small rodents indicates that the apparent lack of rodents at the site is likely a result of collecting bias, rather than preservational bias.

The diminutive size of these incisors and their shape suggest that they could all belong to one species, likely an eomyid, dipodoid, or possibly Microparamys. Though no Eocene eomyids have been documented from the Northwest, there are five Oligocene (Arikareean) eomyid species known from the John Day Formation (Korth and Samuels, 2015) and a number of eomyids known from the middle Eocene of California (Flynn, 2008). Metanoiamys agorus is known from the early Uintan (Ui1) age Friars Formation, and the middle Uintan (Ui2) age Murray Canyon and Mesa Drive Local Faunas (Chiment and Korth, 1996; Flynn, 2008); while $M$. fantasma is known from the Uintan or Duchesnean age Hartman Ranch Local Fauna (Lindsay, 1968). ?Simiacritomys whistleri and Paradjidaumo reynoldsi are known from the Duchesnean age Simi Valley Landfill Local Fauna (Kelly, 1992). In addition to size, the rounded anterior face and relatively thick enamel of the Clarno incisors are similar to other eomyids (Wood, 1974).

Several dipodoids are also known from the middle and late Eocene of California. Simimys simplex is known from several late Uintan (Ui3) and Duchesnean age sites in southern California (Wilson, 1935; Lillegraven and Wilson, 1975; Flynn, 2008). A second species, S. landeri, is known from the Duchesnean age Simi Valley Landfill Local Fauna (Kelly, 1992). Nonomys gutzleri is known from the Duchesnean or early Chadronian (Ch1) age Upper Pomerado Conglomerate (Walsh, 2010). While the incisors or the Bridgerian dipodoid Elymys have rather thin enamel (Emry, 2007), a lower incisor of the Chadronian $N$. simplicidens described by Emry and Dawson (1972) had thick enamel like that of the Clarno incisors, but it is substantially smaller. A single dipodid is known from the Oligocene of Oregon, Plesiosminthus fremdi from the late Arikareean (Ar3) age Kimberly Member of the John Day Formation (Korth and Samuels, 2015).

The incisors from the Hancock Mammal Quarry are also similar in morphology to the smallest members of the Ischyromyidae, including some members of the subfamily Reithroparamyinae (Wood, 1962, 1974; Anderson, 2008). The tiny reithroparamyine ischyromyids Microparamys, Lophiparamys, and Uriscus are known from sites in the western United States, including multiple Uintan age sites in California (Anderson, 2008). Like the Clarno incisors, the incisors of some Microparamys, Lophiparamys, and Uriscus are 1) oval in cross-section, 2) have smooth, round anterior, and lateral enamel surfaces, and 3) a flattened medial surface (Wood, 1962). However, the Clarno specimens are smaller than even the smallest specimens of Reithroparamyinae that have been described (Wood, 1962). The Clarno incisors have thick enamel and no evidence of a groove, unlike Reithroparamys, which has thin enamel and sometimes grooved incisors (Wood, 1962). Unlike the Clarno specimens, the incisors of Acritoparamys have enamel limited to their anterior surface and sometimes bear a shallow groove (Wood, 1962; Korth, 1984). The Clarno incisors also differ substantially from those known of mid and late Eocene geomorph rodents (ex. Heliscomys, Floresomys, Meliakrouniomys), which are strongly laterally compressed (Korth et al., 1991; Flynn et al., 2008).

Family ISCHYROMYIDAE Alston, 1876

Subfamily PARAMYINAE Haeckel, 1895

Tribe MANITSHINI Simpson, 1941

Genus PSEUDOTOMUS Cope, 1872

Type Species. Pseudotomus hians Cope, 1872, by original designation

\section{Pseudotomus sp. \\ (Figure 4; Table 1)}

Referred Specimen. JODA 8900, right m3.

Occurrence. JDNM-83, Whitecap Knoll, Wheeler County, Oregon, Big Basin Member, John Day Formation.

Age. Duchesnean (early late Eocene), between Member A Ignimbrite dated $39.22 \pm 0.03 \mathrm{Ma}$ (Bestland et al., 1999) and Whitecap Knoll Tuff dated $38.4 \pm 0.7 \mathrm{Ma}$ (Manchester, 2000). 


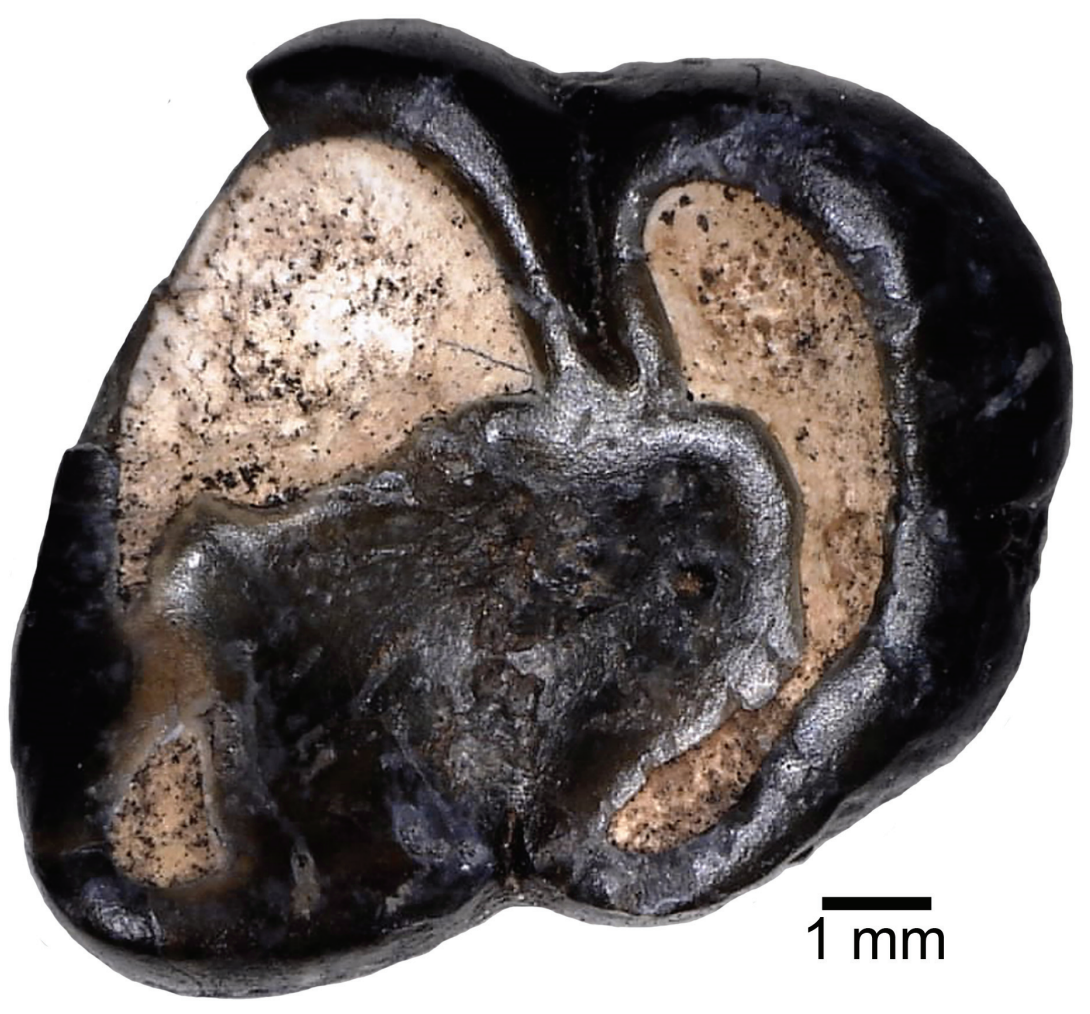

FIGURE 4. Pseudotomus sp. right m3, JODA 8900, from the Big Basin Member of the John Day Formation, Oregon. Scale bar equals $1 \mathrm{~mm}$.

Description. The m3, JODA 8900 , is heavily worn and pitted in places, including the enamel surfaces along the margin of the talonid basin and the posterior portion of the posterolophid. Distinct from the wear and pitting, there is some slight wrinkling of the enamel in the talonid basin. The metaconid is the highest cusp and is more anterior than the protoconid. Due to wear, there is no indication of a trigonid, anterior cingulid, or metalophid. The anterobuccal margin of the protoconid is broken and missing a section of enamel. The protoconid is continuous with the hypoconid via a short ectolophid that is just buccal to the center of the tooth. There is no distinct mesoconid, though there is a swelling within the ectolophid between the protoconid and hypoconid. The tooth is narrower posteriorly, and the posterior cingulid connects the hypoconid and entoconid, forming the posterior

TABLE 1. Dental measurements (in $\mathrm{mm}$ ) of the $\mathrm{m} 3$ of Pseudotomus and Manitsha. Mean values for other taxa were derived from Wood (1962) and Storer (1988). Abbreviations: L, anteroposterior length; aW, transverse width of anterior portion of tooth; pW, transverse width of posterior portion of tooth.

\begin{tabular}{lcccc}
\hline & $\mathbf{L}$ & $\mathbf{a W}$ & $\mathbf{p W}$ & $\mathbf{a W} / \mathbf{L}$ \\
\hline JODA 8900, Pseudotomus sp. & 9.35 & 8.92 & 7.82 & 0.954 \\
P. californicus (Wood, 1962) & 7.03 & 5.64 & 5.45 & 0.802 \\
P. horribilis (Wood, 1962) & 5.93 & 5.34 & 5.30 & 0.901 \\
P. littoralis (Wood, 1962) & 6.6 & 5.2 & 5.0 & 0.788 \\
P. petersoni (Wood, 1962) & 6.26 & 5.65 & 5.26 & 0.903 \\
P. robustus (Wood, 1962) & 6.46 & 5.46 & 5.52 & 0.845 \\
P. timmys (Storer, 1988) & 9.9 & 9.2 & 7.7 & 0.929 \\
Manitsha tanka (Wood, 1962) & 9.37 & 8.50 & 7.83 & 0.907 \\
\hline
\end{tabular}


cingulid. The entoconid is obliquely compressed and a continuation of the posterior cingulid. The anterior transverse width of the tooth is nearly equal to its length (Table 1).

Remarks. JODA 8900 is referred to Pseudotomus based on its large size, simple occlusal morphology, and mesodont crown-height. This specimen is as large as the largest previously described species of Pseudotomus, approximately the same size as P. timmys from the Duchesnean age Lac Pelletier Lower Fauna of Saskatchewan (see tables in Wood, 1962, 1974; Korth, 1985; Storer, 1988; Dunn and Rasmussen, 2007). Unlike JODA 8900, P. timmys has a distinct mesoconid and hypolophid on the $\mathrm{m} 3$ (Storer, 1988). A distinct $\mathrm{m} 3$ mesoconid is also seen in P. californicus, $P$. littoralis, and $P$. robustus (Wood, 1962). The $\mathrm{m} 3$ hypolophid is also present in $P$. californicus, $P$. eugenei, and $P$. littoralis (Wood, 1962; Dunn and Rasmussen, 2007). Though several taxa are represented by material that is too worn or fragmentary to discern these characters, $P$. petersoni is the only known species in the genus that lacks both a distinct $\mathrm{m} 3$ mesoconid and hypolophid, as in JODA 8900. Unlike JODA 8900 and other members of the genus, the Bridgerian P. robustus has a rhomboid-shaped $\mathrm{m} 3$, which is wider posteriorly than anteriorly (Table 1 ).

Though this specimen is similar in size to Manitsha tanka, it is not referable to that genus because it lacks the distinct and complete hypolophid present within the $\mathrm{m} 3$ talonid basin of the latter (Simpson, 1941). Interestingly, the proportions are also distinct from Manitsha; while having nearly identical length, the anterior portion of the tooth is substantially wider in JODA 8900 (Table 1). JODA 8900 is actually wider relative to its length than any described manitschine ischyromyid. JODA 8900 also differs from the large Duchesnean Quadratomus gigans (Wood, 1974) in being higher-crowned and not as squared in occlusal outline.

Contemporaneous species of Pseudotomus include $P$. johanniculi and $P$. petersoni from the Duchesnean Porvenir Local Fauna of Texas (Wood, 1974), and P. timmys from the Duchesnean Lac Pelletier Lower Fauna from Saskatchewan (Storer, 1988). JODA 8900 predates the appearance of Manitsha by several million years, M. tanka is known only from the Orellan Scenic Member of the Brule Formation in South Dakota (Simpson, 1941). Manitsha sp. was reported from the midChadronian (Ch2) Airstrip Local Fauna of Texas (Wood, 1962), but material was limited to a single partial incisor, which was similar in size to $M$. tanka but differed in proportions.
Subfamily ISCHYROMYINAE Alston, 1876

Included Genera. Ischyromys Leidy, 1856 (including Titanotheriomys Matthew, 1910); Spurimus Black, 1971; and Proischyromys n. gen.

Range. Late Uintan (middle Eocene; Ui3) to early Whitneyan (early Oligocene; Wh1) of western North America.

Definition. Small to intermediate sized ischyromyids with brachydont to mesodont and lophate cheek teeth; hypocones large on upper molars; lower molars with: 1) hypolophid complete, 2) mesoconid lacking, 3) metalophulid II complete enclosing trigonid basin posteriorly, 4) entoconid separated from posterior cingulid by deep valley.

Remarks. There has been a debate over several decades as to the validity of Titanotheriomys as a distinct genus or subgenus of Ischyromys (Black, 1968; Wood, 1976, Heaton, 1996; also see discussion in Korth, 1994:49). This taxonomic question will not be addressed here, and any reference to Ischyromys will include all species previously referred to either the latter or Titanotheriomys for convenience.

Previously, Ischyromys (including Titanotheriomys) has been the only genus referred to the subfamily Ischryomyinae (Korth, 1994; McKenna and Bell, 1997; Anderson, 2008). Wood (1937, 1955, 1962, 1976, 1980) recognized it as the family Ischyromyidae rather than a subfamily, but also limited it to Ischyromys. This genus (and subfamily) was the latest occurring of the Ischyromyidae, originating in the Duchesnean and continuing through the Whitneyan (Korth, 1994). Anderson (2008, figure 18.3) illustrated the range of Ischyromys extending back into the Washatchian, but this cannot be verified and seems to have been in error. Only a single occurrence prior to the Duchesnean is listed in Anderson (2008), Ischyromys cf. douglassi from the late Uintan (Ui3) Hough Draw Local Fauna in Montana that appeared as ?/schyromys sp. on a faunal list by Tabrum et al. (1996).

No earlier or contemporaneous genus has been identified as ancestral or closely related to Ischyromys in the past. However, it appears that Spurimus and a new genus described below occur earlier and are morphologically more primitive than Ischyromys and are here referred to the subfamily. Anderson (2008) suggested that Ischyromys was closely related to the microparamyines (see Anderson, 2008, figure 18.2). However, this is very unlikely due to the overall size, degree of lophodonty, and other characteristic features of Ischyromys. Ischyormys also lacks the diagnostic 
characters of a microparamyine (Wood, 1962; Korth, 1994; Anderson, 2008).

Black (1971) first described the rodent Spurimus from the Badwater fauna of central Wyoming, recognizing two species $S$. selbyi and $S$. scottii (type species) from the Uintan and Duchesnean, respectively. Both species were represented by isolated cheek teeth only. He placed the genus in the subfamily Prosciurinae of the family Ischyromyidae. Additional specimens of an indeterminate species of Spurimus were reported later from the earliest Chadronian of Wyoming (Sutton and Black, 1975). Shortly afterward, Rensberger (1975) placed the Prosciurinae (along with Spurimus) in the family Aplodontiidae, an allocation that has been followed by most subsequent authors (e.g., Wood, 1980; Korth, 1994). McKenna and Bell included Spurimus in the family Allomyidae within the superfamily Aplodontoidea. Flynn and Jacobs (2008) included Spurimus in the Aplodontiidae along with several other early genera as "basal aplodontids." In all these cases, Spurimus has been associated taxonomically with the aplodontiids.

However, in recent cladistic analyses of the Aplodontoidea, Spurimus has been purposely excluded from consideration (Hopkins, 2008; Vianey-Liaud et al., 2013). Rensberger (1975) was the first to question the inclusion of Spurimus in the Prosciurinae based on a number of dental morphologies that differed from prosciurines (upper molars: protocone directly connected to protoconule, low anterior cingulum, large hypocone, metaloph connects metaconule and metacone at apices; lower molars: mesoconid minute or lacking, hypolophid high and distinct; also see Wood, 1980). The dental features cited by Rensberger (1975) are all characteristic of Ischyromys. Spurimus is clearly separable from Ischyromys by its much smaller size and brachydont cheek teeth that are markedly less lophate. Spurimus has lower molars ( $\mathrm{m} 1$ and $\mathrm{m} 2)$ that are longer than wide, while the $\mathrm{m} 1$ and $\mathrm{m} 2$ are typically equidimensional or wider than long in Ischyromys. However, the large hypocone and metaloph morphology of the upper molars and the well-developed hypolophid and lack of a mesoconid on the lower molars observed in Spurimus are more similar to the features of Ischyromys than prosciurine aplodontiids, which have a small to minute hypocone and a metaloph that connects the metacone and metaconule along their anterior edges on the upper molars, and a weak or incomplete hypolophid and distinct mesoconid on the lower molars. The new genus described below has these same shared characters of the lower molars seen in Spurimus and Ischyromys, and is therefore assignable to the Ischyromyinae, but clearly distinct from both of these latter genera.

\section{Genus PROISCHYROMYS n. gen.}

\section{zoobank.org/B2A8C0C3-6A38-4A8E-A916-D2063D7C0EED}

Type Species. Proischyromys perditus n. gen., n. sp.

Range. Late Eocene (Chadronian) of Oregon.

Diagnosis. Cheek teeth brachydont; m1-m2 wider than long; trigonid basin on $\mathrm{m} 1-\mathrm{m} 2$ enclosed anteriorly by metalophulid I (=anterior cingulid) and posteriorly by metalophulid II; low, broad loph extending into center of the lower molars distobuccally from metaconid on $\mathrm{m} 1-\mathrm{m} 2$.

Etymology. Greek, pro-, prefix meaning before; intended to indicate the more primitive morphology of the genus relative to Ischyromys.

Remarks. Proischyromys n. gen. is referred to the Ischyromyinae because of the lophodonty and morphology of the lower molars. It shares with Ischyromys: 1) a complete hypolophid; 2) lack of a mesoconid; 3) short ectolophid situated well lingual to the buccal margin of the tooth; 4) entoconid separated from posterolophid by deep notch; and 5) metalophulid II complete, enclosing trigonid basin posteriorly on m1-m2. Proischyromys n. gen. differs from Ischyromys in: 1) smaller size (equal to only the smallest specimens of Ischyromys [see Table 2; Heaton, 1996]); 2) brachydont cheek teeth (mesodont in Ischyromys); trigonid closed anteriorly by anterior cingulid (open at base of metaconid in Ischyromys); and 3) low, broad lophid extending distobuccally from the metaconid on m1-m2. Proischyromys $\mathrm{n}$. gen. differs from Reithroparamyinae in: 1) complete hypolophid on m1-2; 2) low, broad lophid extending distobuccally from the metaconid on $\mathrm{m} 1-\mathrm{m} 2$; and 3 ) buccal aspect of the posterolophid does not extend posterior to the entoconid.

Proischyromys n. gen. also shares the complete hypolophid, lack of a mesoconid, and separation of the entoconid from the posterolophid with Spurimus. The molars of Proischyromys $\mathrm{n}$. gen. differ from those of Spurimus in: 1) being larger with higher and better developed lophs; 2) having a complete metalophulid II on m1-m2; and 3) m1-m2 wider than long (longer than wide in Spurimus). Proischyromys $\mathrm{n}$. gen. also lacks the distinct notch and cuspule anterior to the protoconid present on the lower molars of $S$. scottii (not present on S. selbyi). 


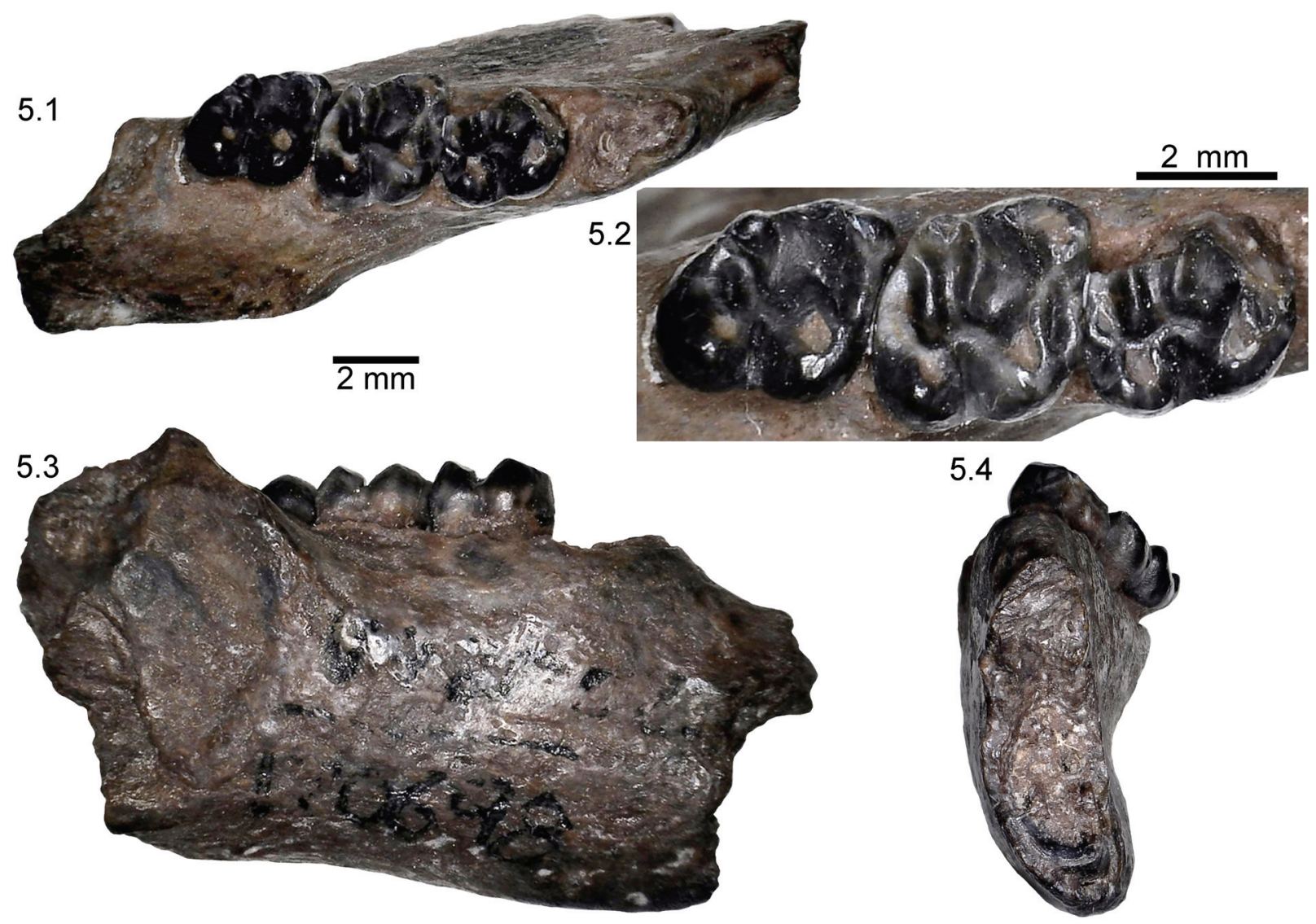

FIGURE 5. Proischyromys perditus n. gen., n. sp. right dentary with m1 - m3, UCMP 170698, from the Big Basin Member of the John Day Formation, Oregon. 5.1. occlusal view, 5.2. enlarged occlusal view, 5.3. lateral view, 5.4. anterior view. Scale bars equal $2 \mathrm{~mm}$.

Proischyromys perditus n. gen., n. sp.

(Figure 5; Table 2)

zoobank.org/260754CE-F428-4741-AB2B-15409A4812EE

Type and Only Specimen. UCMP 170698, right dentary with $\mathrm{m} 1$ to $\mathrm{m} 3$.

Occurrence. UC V92002, Lost Creek, Crook County, Oregon, Big Basin Member, John Day Formation.

Age. Chadronian (late Eocene, Ch2 or later), above White Ash of Post dated 36.21 $\pm 0.26 \mathrm{Ma}$ (Manchester and McIntosh, 2007).

Diagnosis. Only species of the genus.

Etymology. Latin, perditus, adjective meaning lost; referring both to the name of the site where it was found and the long missing Eocene fauna to which this rodent belongs.

Description. The dentary is typical of ischyromyids in its primitive morphology. The masseteric scar extends anteriorly in a U-shape to a point below $\mathrm{m} 2$. The ascending ramus originates lateral to the anterior margin of $\mathrm{m} 3$, blocking only the posterior half of $\mathrm{m} 3$ from lateral view. The dorsal margin of the diastema is shallow. The incisor is much longer than wide in cross-section and rounded anteriorly.

Only the alveoli for p4 are preserved. The tooth is the smallest of the cheek teeth, two-rooted, and narrower anteriorly than posteriorly. The $\mathrm{m} 1$ is broken along the lingual edge of the tooth, so the metaconid and entoconid are lacking. The $\mathrm{m} 1$ trigonid is a small basin anterolingual to the protoconid. It is enclosed both anteriorly and posteriorly by the anterior cingulid and metalophulid II, respectively. A low, broad lophid runs distobuccally along the posterior margin of the metalophulid II and is separated from the ectolophid by a gap. The ectolophid extends posterolingually from the protoconid, and then turns posterobuccally at the junction with the hypolophid. The re-entrant valley between the protoconid and hypoconid is narrow, oriented posterolingually, and extends approximately $1 / 3$ the width of the tooth. The hypoconid is round and slightly anteroposteriorly compressed. The posterior cingluid extends lingually from its posterolin- 
TABLE 2. Dental measurements (in $\mathrm{mm}$ ) of the holotype of Proischyromys perditus n. gen., n. sp. (UCMP 170698), as well as species of Ischyromys and Spurimus. Mean values for other taxa were derived from listed literature sources. Length of the tooth row (p4-m3L) was measured at the alveolar level. Abbreviations: L, anteroposterior length; W, transverse width.

\begin{tabular}{lccccccccc}
\hline & iL & iW & m1L & m1W & m2L & m2W & m3L & m3W & p4-m3L \\
\hline Proischyromys perditus n. gen., n. sp. & 4.03 & 1.88 & 3.01 & - & 2.98 & 3.06 & 3.04 & 2.81 & 12.30 \\
Ischyromys typus (Wood, 1937) & - & - & 3.69 & 3.41 & 3.68 & 3.53 & 3.99 & 3.32 & 14.36 \\
I. blacki (Wood, 1974) & $\sim 4.6$ & - & - & - & 2.94 & 3.36 & 3.56 & 3.20 & 13.0 \\
I. douglassi (Black, 1968) & - & - & 3.65 & 3.61 & 3.71 & 3.82 & 3.84 & 3.81 & 15.6 \\
I. junctus (Russell, 1972) & - & - & - & - & 2.94 & 3.03 & 3.40 & 3.00 & - \\
I. parvidens (Wood, 1937) & - & - & 2.97 & 2.64 & 2.77 & 2.91 & 3.38 & 2.81 & 12.16 \\
I. pliacus (Wood, 1937) & - & - & 3.76 & 3.89 & 3.89 & 3.97 & 4.1 & 3.6 & 16.4 \\
I. veterior (Wood, 1974) & 3.23 & 1.74 & 3.47 & 3.21 & 3.57 & 3.48 & 2.98 & 2.72 & 14.4 \\
Spurimus scottii (Black, 1971) & - & - & 2.18 & 1.95 & - & - & - & 2 & - \\
S. selbyi (Black, 1971) & - & - & 2.23 & 2.11 & - & - & 2.3 & 2 & - \\
\hline
\end{tabular}

gual corner. A small but distinct hypoconulid is present on the posterior cingulid just lingual to its junction with the hypoconid. The hypolophid extends directly lingual from the ectolophid. The valley between the posterolophid and the hylolophid is narrow and deep. The valley that separates the hypolophid from the metalophid II is broader, and there is a broad sloping surface extending buccally from the base of the metaconid.

The $\mathrm{m} 2$ is similar to $\mathrm{m} 1$ in morphology but is complete, with only a small chip of enamel missing off of the lingual slope of the metaconid. The metaconid is large and slightly anteriorly placed relative to the protoconid and is slightly obliquely compressed. There is a minute swelling along the posterolingual slope of the metaconid that may indicate the presence of a metastylid, but this cannot be verified due to breakage. The trigonid basin is a narrow valley between the anterior cingulid and the metalophulid II, both of which are complete from the metaconid to the protoconid. The hypoconid and ectolophid are as in $\mathrm{m} 1$, but the ectolophid is slightly more lingually placed, making the reentrant valley slightly deeper than in $\mathrm{m} 1$. The hypoconid is round in occlusal shape, and as in $\mathrm{m} 1$ the posterior cingulid extends lingually from its posterolingual corner. The posterolophid is broad, and due to wear it is impossible to determine whether a distinct hypoconulid was present. The hypolophid extends to a prominent entoconid and is separated from the posterior cingulid by a deep, narrow valley. Anterior to the hypolophid is a shallower and broader valley. There is a low, broad lophid extending distobuccally from the metaconid along the posterior margin of the metalophulid II. The loph is separated from the ectolophid by a small gap and is slightly more distinct than in $\mathrm{m} 1$.

The $\mathrm{m} 3$ is the smallest of the molars. Unlike the other molars, the trigonid is not closed posteriorly, as the posterior arm of the protoconid extends less than half the distance to the metaconid. The anterior cingulid is complete. The protoconid and ectolophid are similar to those of the anterior molars. The entoconid on $\mathrm{m} 3$ is isolated from the hypolophid. The hypolophid originates at the ectolophid as in the anterior molars, but extends in a more posterolingual direction, joining the lingual end of the posterior cingulid, posterior and buccal to the entoconid. The posterior cingulid and the hypolophid enclose a narrow slit-like basin. On the posterolingual slope of the metaconid are two minute cuspules (metastylids). There is no indication of an accessory loph extending lingually from the metaconid as in $\mathrm{m} 1$ or $\mathrm{m} 2$.

The lower incisor is broken, but an oval crosssectional shape is clearly visible. The anterior and lateral surfaces of the incisor are round and the medial edge is flat. The enamel surface is smooth, and limited to the anterior face and about $1 / 3$ of the lateral face of the incisor. The tooth is much deeper anteroposteriorly than it is transversely wide.

Discussion. The morphology and size of the lower molars of Proischyromys perditus n. gen., n. sp. are clearly intermediate between those of Spurimus and Ischyromys. In crown-height the molars of $P$. perditus n. gen., n. sp. are higher than those of Spurimus and lower than all species of Ischyromys. Similarly, the degree of lophodonty (height and completeness of lophs) in the molars of Proischyromys n. gen. is greater than in Spurimus and less than in Ischyromys. 
Since the occurrence of Proischyromys $\mathrm{n}$. gen. is from above an ash dated $36.21 \mathrm{Ma}$, it is late early Chadronian (Ch2) in age or younger. Presence of both Megacerops and Mesohippus at the Lost Creek site confirm that the site is late Eocene (Chadronian) in age, rather than early Oligocene. This means that $P$. perditus $\mathrm{n}$. gen., $\mathrm{n}$. sp. is likely later than any records of Spurimus, which is known from the late Uintan to earliest Chadronian (Black, 1971; Flynn and Jacobs, 2008). The latest described record of Spurimus is from the Pilgrim Creek Local Fauna of Wyoming, which is earliest Chadronian in age (Sutton and Black, 1975). Proischyromys $\mathrm{n}$. gen. also predates most records of Ischyromys, which is known from the Duchesnean to the Whitneyan (Korth, 1994; Flynn and Jacobs, 2008).

Records of Ischyromys that predate the appearance of Proischyromys perditus n. gen., n. $\mathrm{sp}$. include several occurrences from the Duchesnean and earliest Chadronian. Duchesnean occurrences include: 1) ?/schyromys sp. from the Badwater fauna, Wyoming (Black, 1971, figures 51-73), 2) Ischyromys sp. from the Lac Pelletier Lower Fauna in Saskatchewan (Storer, 1988; Heaton, 1996), and 3) I. blacki from the Vieja Group in Texas (Wood, 1974, figure 10; Flynn and Jacobs, 2008). Earliest Chadronian occurrences include Ischyromys junctus from the Calf Creek Local Fauna of Saskatchewan (Russell, 1972) and an unnamed species from West Canyon Creek in Wyoming (Heaton, 1996). Ischyromys sp. has been noted from the late Duchesnean or early Chadronian (Ch1) Upper Conglomerate Member of the Pomerado Conglomerate in California (Walsh and Gutzler, 1999)

All of the earliest Ischyromys species have cheek teeth that are higher crowned than in Proischyromys perditus $\mathrm{n}$. gen., $\mathrm{n}$. $\mathrm{sp}$. The $\mathrm{m} 3$ of $P$. perditus n. gen., n. sp. is shorter, relative to the $\mathrm{m} 2$, than in any other ischyromyid studied (Table 2). In particular, both $I$. blacki and I. parvidens have a much longer $\mathrm{m} 3$ relative to $\mathrm{m} 2$ than in $P$. perditus $\mathrm{n}$. gen., n. sp., as well as other species of Ischyromys (Table 2; Wood, 1974; Heaton, 1996). The unnamed species of Ischyromys from Wyoming (Heaton, 1996) also has accessory cuspules on the molars that are not present in $P$. perditus $\mathrm{n}$. gen., n. sp. The only described species of Ischyromys as small as P. perditus n. gen., n. sp. is I. parvidens from the Orellan of South Dakota and Nebraska (Table 2; Wood, 1937).

\section{DISCUSSION}

The rodents described here are the first Eocene rodents, and include the first ischyromyids, to be described from the Pacific Northwest. While the Oligocene and Miocene rodents of the John Day Basin are well studied, these new specimens help to fill an important gap in our knowledge of Cenozoic faunas from the region. The presence of diminutive rodents in the Hancock Mammal Quarry points to the possibility of finding more small vertebrates from the Clarno Formation. Given the composition of known faunas from Clarno and later Cenozoic faunas in Oregon, additional finds from Clarno would almost certainly yield previously unknown taxa. The ischyromyids from the Big Basin Member of the John Day Formation are the first mammals identified and described from those strata, though some taxa have appeared in faunal lists (Fremd et al., 1994; Fremd, 2010). Also particularly noteworthy is that the ischyromyid from Lost Creek is part of the only Chadronian fauna later than Ch1 known from west of the Rocky Mountains.

While fragmentary and limited in nature, these specimens do allow comparisons to be made with contemporaneous rodent faunas from California (Table 3), which are the only others from the Pacific Coast of North America. While the incisors from the Clarno formation described above cannot be definitively identified, there are multiple rodent taxa with comparable incisors recorded in the middle and late Eocene of California, including a number of eomyids and dipodoids, and several species of Microparamys. The Duchesnean occurrence of Pseudotomus from Whitecap Knoll is substantially later than California occurrences of the genus, which are restricted to the early and middle Uintan. The only records of the genus as late as the specimen from Oregon are Duchesnean occurrences from Texas (Wood, 1974) and Saskatchewan (Storer, 1988). Only one record of the Ischyromyinae has been reported from west of the Rocky Mountains, Ischyromys sp. from the late Duchesnean or early Chadronian (Ch1) Upper Conglomerate Member of the Pomerado Conglomerate in California (Walsh and Gutzler, 1999).

The Eocene rodents described here inhabited paleoenvironments quite different from those encountered by the well-known Oligocene rodents in Oregon. Fossil floras and paleosols from the Eocene and Oligocene of Oregon document dramatic shifts in climate, with conditions becoming cooler, drier, and more seasonal through the late Eocene and early Oligocene (Meyer and Manches- 
TABLE 3. Comparison of some Eocene rodent faunas from Oregon and California.

\begin{tabular}{|c|c|c|}
\hline Fauna & Taxa & Age \\
\hline Friars Fm., California & $\begin{array}{l}\text { Microparamys minutus } \\
\text { Microparamys woodi } \\
\text { Pseudotomus californicus } \\
\text { Pseudotomus littoralis } \\
\text { ?Uintaparamys caryophilus } \\
\text { Uriscus californicus } \\
\text { Sciuravus powayensis } \\
\text { Pareumys granger } \\
\text { Metanoiamys agorus }\end{array}$ & Early Uintan (Ui1) \\
\hline Santiago Fm., California & $\begin{array}{l}\text { Eohaplomys serus } \\
\text { Eohaplomys tradux } \\
\text { Microparamys minutus } \\
\text { Microparamys tricus } \\
\text { Microparamys woodi } \\
\text { Pseudotomus sp. } \\
\text { Rapamys fricki } \\
\text { Sciuravus powayensis } \\
\text { Metanoiamys agorus } \\
\text { Griphomys alecer }\end{array}$ & Uintan (Ui2 - Ui3) \\
\hline $\begin{array}{l}\text { Brea Canyon Local Fauna, } \\
\text { Sespe Fm., California }\end{array}$ & $\begin{array}{l}\text { Eohaplomys matutinus } \\
\text { Eohaplomys serus } \\
\text { Eohaplomys tradux } \\
\text { Mytonomys burkei } \\
\text { Metaparamys compressidens } \\
\text { Rapamys fricki } \\
\text { Reithroparamys sp. } \\
\text { Tapomys tapensis } \\
\text { Uintaparamys leptodus } \\
\text { ?Uintaparamys caryophilus } \\
\text { Pareumys milleri } \\
\text { Metanoiamys marinus } \\
\text { Griphomys alecer }\end{array}$ & Late Uintan (Ui3) \\
\hline Hancock Quarry, Clarno Fm., Oregon & Rodentia incertae sedis & $\begin{array}{l}\text { Late Uintan (Ui3) or } \\
\text { Duchesnean }\end{array}$ \\
\hline Whitecap Knoll, John Day Fm., Oregon & Pseudotomus sp. & Duchesnean \\
\hline $\begin{array}{l}\text { Pearson Ranch Local Fauna, } \\
\text { Sespe Fm., California }\end{array}$ & $\begin{array}{l}\text { Microparamys tricus } \\
\text { Microparamys woodi } \\
\text { Uintaparamys sp. } \\
\text { Pareumys milleri } \\
\text { Presbymys lophatus } \\
\text { Griphomys alecer }\end{array}$ & Duchesnean \\
\hline $\begin{array}{l}\text { Simi Valley Landfill Local Fauna, Sespe } \\
\text { Fm., California }\end{array}$ & $\begin{array}{l}\text { Simimys landeri } \\
\text { Simimys simplex } \\
\text { ?Simiacritomys whistleri } \\
\text { Metanoiamys korthi } \\
\text { Paradjidaumo reynoldsi } \\
\text { Heliscomys walshi }\end{array}$ & Duchesnean \\
\hline $\begin{array}{l}\text { Upper Conglomerate Member, } \\
\text { Pomerado Conglomerate, California }\end{array}$ & $\begin{array}{l}\text { Ischyromys sp. } \\
\text { Metanoiamys sp. } \\
\text { Protadjidaumo sp. } \\
\text { cf. Paradjidaumo sp. } \\
\text { cf. Griphomys sp. } \\
\text { Heliscomys sp. } \\
\text { Nonomys gutzleri } \\
\text { Unnamed Nonomyinae }\end{array}$ & $\begin{array}{l}\text { Late Duchesnean or Early } \\
\text { Chadronian (Ch1) }\end{array}$ \\
\hline Lost Creek, John Day Fm., Oregon & Proischyromys perditus n. gen., n. sp. & Chadronian (Ch2 or later) \\
\hline
\end{tabular}


ter, 1997; Manchester, 2000; Myers, 2003; Retallack et al., 2000; Retallack, 2007; Dillhoff et al., 2009). Ecosystems transitioned from subtropical forests in the middle Eocene to temperate forests in the late Eocene and partially open woodlands in the early Oligocene. The absence of similarity to later rodent faunas may be a consequence of the climate and habitat changes associated with the Eocene / Oligocene transition.

Interestingly, all of the sites that have yielded Eocene rodents in Oregon actually have associated floras, which facilitate direct interpretation of habitat conditions. Leaf-bearing shales from the Hancock Mammal Quarry have yielded a small flora (McKee, 1970; Retallack et al., 1996), which is entirely composed of angiosperms and lacks the thermophilic species that dominate the earlier Clarno Nut Beds (Bestland and Retallack, 1994a; Dillhoff et al., 2009). While the flora indicates a cooler and seasonally drier climate than was present earlier in the Eocene, the presence of an alligator at the site (Hanson, 1996) suggests there were still frost-free conditions in the forests of Oregon around $40 \mathrm{Ma}$. The approximately 38.8 Ma Whitecap Knoll flora from the base of the John Day Formation is dominated by temperate forest taxa, but does retain a number of broadleaf evergreen taxa that are present in earlier Clarno floras and considered indicative of frost-free conditions (Manchester, 2000; Dillhoff et al., 2009). Clarno species that persist into the Whitecap Knoll flora include Ailanthus and Eucommia, while some species not known from Clarno, like Rosa and Catalpa, appear at Whitecap Knoll and persist into the early Oligocene Bridge Creek flora (Manchester, 2000). Interestingly, the Whitecap Knoll flora is devoid of conifers, which dominate the assemblages of the later Bridge Creek flora (Meyer and Manchester, 1997; Manchester, 2000; Dillhoff et al., 2009).

Floras from along the Crooked River near Post have been described in a number of studies (Chaney, 1927; Meyer and Manchester, 1997; Wheeler et al., 2006, Manchester and Mclntosh, 2007). Leaves from Lost Creek were previously described as an assemblage of the Oligocene Bridge Creek Flora, but radiometric data presented in Manchester and Mclntosh (2007) indicated that the floras of Lost Creek are late Eocene in age, occurring below the $36.21 \mathrm{Ma}$ White Ash of Post. Meyer and Manchester (1997) also noted differences in the taxonomic composition of Lost Creek from other assemblages; it includes leaves from five conifer species, of which Sequoia and Tetraclinis are unknown from the Oligocene assem- blages of the Bridge Creek flora. Silicified fruits and seeds occur below the White Ash of Post and include many thermophilic taxa known from the middle Eocene Clarno Nut Beds, but also a number of deciduous taxa common in the Oligocene Bridge Creek flora (Manchester and Mclntosh, 2007). The abundance of ring porous and semiring porous woods in the same strata suggests more seasonal conditions than were present in the middle Eocene (Wheeler et al., 2006). Together, the late Eocene floras near Post indicate a transition to cooler and more seasonal temperate forests than were present earlier in the Eocene.

\section{CONCLUSIONS}

These new finds highlight the potential for the discovery of new taxa, even in well-studied sties. The Eocene rodents of Oregon will help facilitate more detailed faunal comparisons with similar aged sites in California and the Great Plains, and contribute to study of how early rodent clades evolved and dispersed. Improved understanding of smaller vertebrates from Eocene sites in the Pacific Northwest will also allow more complete examination of how faunas responded to climate and habitat changes associated with the EoceneOligocene transition.

\section{ACKNOWLEDGMENTS}

This work was supported in part by the National Park Service and John Day Fossil Beds National Monument. P. Holroyd (UCMP) and E. Davis and S. Hopkins (UOMNH) graciously granted access to specimens in their care. We also thank J. Kerby, B. Gray, and E. Barnholdt for permitting and assisting with work on the Nature Conservancy land in Oregon, which was vital for understanding the context of specimens described here.

\section{REFERENCES}

Albright III, L.B., Woodburne, M.O., Fremd, T.J., Swisher III, C.C., MacFadden, B.J., and Scott, G.R. 2008. Revised chronostratigraphy and biostratigraphy of the John Day Formation (Turtle Cove and Kimberly Members), Oregon, with implications for updated calibration of the Arikareean North American Land Mammal Age. The Journal of Geology, 116:211-237.

Alston, E.R. 1876. On the classification of the order Glires. Proceedings of the Zoological Society of London, 1876:61-98.

Anderson, D. 2008. Ischyromyidae, p. 311-325. In Janis, C.M., Gunnell, G.F., and Uhen, M.D. (eds.), Evolution 
of Tertiary Mammals of North America. Volume 2: Small Mammals, Xenarthrans, and Marine Mammals. Cambridge University Press, New York.

Bestland, E.A., Hammond, P.E., Blackwell, D.L.S., Kays, M.A., Retallack, G.J., and Stimac, J. 1999. Geologic framework of the Clarno Unit, John Day Fossil Beds National Monument: Central Oregon. Oregon Geology, 61:3-19.

Bestland, E.A. and Retallack, G.J. 1994a. Geology of the Clarno Unit, John Day Fossil Beds National Monument, Oregon. Final report, National Park Service contract CX-9000-1-10009.

Bestland, E.A. and Retallack, G.J. 1994b. Geology and paleoenvironments of the Painted Hills Unit, John Day Fossil Beds National Monument, Oregon. National Park Service Final report, contract CX9000-1-10009.

Black, C.C. 1968. The Oligocene rodent Ischyromys and discussion of the family Ischyromyidae. Annals of Carnegie Museum, 39:273-305.

Black, C.C. 1971. Paleontology and geology of the Badwater Creek area, central Wyoming. Part 7. Rodents of the family Ischyromyidae. Annals of Carnegie Museum, 43:179-217.

Bowdich, T. 1821. An Analysis of the Natural Classification of Mammalia for the Use of Students and Travelers. J. Smith, Paris.

Brown, R.W. 1959. A bat and some plants from the Upper Oligocene of Oregon. Journal of Paleontology, 33:125-129.

Cavender, T. 1969. An Oligocene mudminnow (Family Umbridae) from Oregon with remarks on relationships within the Esocoidei. Occasional Papers of the Museum of Zoology, University of Michigan, 660:133.

Chaney, R.W. 1924. Quantitative studies of the Bridge Creek Flora. American Journal of Science, Fifth Series, VIII:127-144.

Chaney, R.W. 1927. Geology and paleontology of the Crooked River Basin, with special reference to the Bridge Creek flora. Carnegie Institute of Washington Publications, 346:45-138.

Chaney, R.W. 1948. The ancient forests of Oregon. Oregon System of Higher Education, Condon Lectures, Eugene, Oregon, 56 pp.

Chiment, J.J. and Korth, W.W. 1996. A new genus of eomyid rodent (Mammalia) from the Eocene (UintanDuchesnean) of Southern California. Journal of Vertebrate Paleontology, 16:116-124.

Coleman, R.G. 1949. The John Day Formation in the Picture Gorge Quadrangle, Oregon. Unpublished Master of Science Thesis, Oregon State College, Corvallis, Oregon, USA.

Cope, E.D. 1872. Second account of new Vertebrata from the Bridger Eocene. Proceedings of the American Philosophical Society, 12:466-468.

Dillhoff, R.M., Dillhoff, T.A., Dunn, R.E., Myers, J.A., and Strömberg, C.A.E. 2009. Cenozoic paleobotany of the John Day Basin, central Oregon, p. 135-164. In
O'Connor, J.E., Dorsey, R.J., and Madin, I.P. (eds.), Volcanoes to Vineyards: Geologic Field Trips through the Dynamic Landscape of the Pacific Northwest. Geological Society of America Field Guide 15.

Dunn, R.H. and Rasmussen, D.T. 2007. Skeletal morphology and locomotor behavior of Pseudotomus eugenei (Rodentia, Paramyinae) form the Uinta Formation, Utah. Journal of Vertebrate Paleontology, 27:987-1006.

Emery, M.M., Davis, E.B., and Hopkins, S.S.B. 2016. Systematic reassessment of an agriochoerid oreodont from the Hancock Mammal Quarry, Clarno (Eocene, Duchesnean), Oregon. Journal of Vertebrate Paleontology, 36(2):e1041970.

Emry, R.J. 2007. The middle Eocene North American myomorph rodent Elymys, her Asian sister Aksyiromys, and other Eocene myomorphs. Bulletin of Carnegie Museum of Natural History, 39:141-150

Emry, R.J. and Dawson, M.R. 1972. A unique cricetid (Rodentia, Mammalia) from the Early Oligocene of Natrona County, Wyoming. American Museum Novitates, 2508:1-14.

Fisher, R.V. and Rensberger, J.M. 1972. Physical stratigraphy of the John Day Formation, central Oregon. University of California Publications in Geological Sciences, 101:1-33.

Flynn L.J. 2008. Eomyidae, p. 415-427. In Janis, C.M., Gunnell, G.F., and Uhen, M.D. (eds.), Evolution of Tertiary Mammals of North America. Volume 2: Small Mammals, Xenarthrans, and Marine Mammals. Cambridge University Press, New York.

Flynn, L.J. and Jacobs, L.L. 2008. Aplodontoidea, p. 377-390. In Janis, C.M., Gunnell, G.F., and Uhen, M.D. (eds.), Evolution of Tertiary Mammals of North America. Volume 2: Small Mammals, Xenarthrans, and Marine Mammals. Cambridge University Press, New York.

Fremd, T.J. 2010. Guidebook: SVP Field Symposium 2010, John Day Basin Field Conference. Society of Vertebrate Paleontology.

Fremd, T.J., Bestland, E.A., and Retallack, G.J. 1994. John Day Basin paleontology field trip guide and road log for the Society of Vertebrate Paleontology Annual Meeting. Northwest Interpretive Association, Seattle.

Haeckel, E. 1895. Systematische Phylogenie der Wirbelthiere (Vertebrata). Dritter Theil des Entwurfes einer systematischen Stammesgeschichte. Verlag von Georg Reimer, Berlin.

Hanson, C.B. 1989. Teletaceras radinskyi, a new primitive rhinocerotid from the late Eocene Clarno Formation of Oregon. p. 235-256. In Prothero, D.R. and Schoch, R.M. (eds.), The Evolution of Perissodactyls. Oxford University Press, New York.

Hanson, C.B. 1996. Stratigraphy and vertebrate faunas of the Bridgerian-Duchesnean Clarno Formation, north-central Oregon, p. 206-239. In Prothero, D.R. and Emry, R.J. (eds.), The Terrestrial Eocene-Oligo- 
cene Transition in North America. Cambridge University Press, Cambridge.

Hay, R.L. 1963. Stratigraphy and zeolitic diagenesis of the John Day Formation of Oregon. University of California Publications in Geological Sciences. 42:199262.

Heaton, T.H. 1996. Ischyromyidae, p. 373-398. In Prothero, D.R. and Emry, R.J. (eds.), The Terrestrial Eocene-Oligocene Transition in North America. Cambridge University Press, Cambridge.

Hopkins, S.S.B. 2008. Phylogeny and evolutionary history of the Aplodontoidea (Mammalia: Rodentia). Zoological Journal of the Linnean Society, 153:769838.

Hunt, R.M., Jr., and Stepleton, E. 2004. Geology and paleontology of the upper John Day beds, John Day River Valley, Oregon: lithostratigraphic and biochronologic revision in the Haystack Valley and Kimberly areas (Kimberly and Mt. Misery quadrangles). Bulletin of the American Museum of Natural History, 282:1-90.

Kelly, T.S. 1992. New Uintan and Duchesnean (middle and late Eocene) rodents from the Sespe Formation, Simi Valley, California. Southern California Academy of Sciences Bulletin, 91:97-120.

Korth, W.W. 1984. Earliest Tertiary evolution and radiation of rodents in North America. Bulletin of the Carnegie Museum of Natural History, 245:1-71.

Korth, W.W. 1985. The rodents Pseudotomus and Quadratomus and the content of the tribe Manitshini (Paramyinae, Ischromyidae). Journal of Vertebrate Paleontology, 5:139-152.

Korth, W.W. 1994. The Tertiary Record of Rodents in North America. Plenum Press, New York.

Korth, W.W. and Samuels, J.X. 2015. New rodent material from the John Day Formation (Arikareean, Middle Oligocene to Early Miocene) of Oregon. Annals of Carnegie Museum, 83:19-84.

Korth, W.W., Wahlert, J.H., and Emry, R.J. 1991. A new species of Heliscomys and recognition of the family Heliscomyidae (Geomyoidea:Rodentia). Journal of Vertebrate Paleontology, 11:247-256.

Leidy, J. 1856. Notices of remains of extinct Mammalia discovered by Dr. F.V. Hayden in Nebraska Territory. Proceedings of the Academy of Natural Sciences, Philadelphia, 8:88-90.

Lillegraven, J.A. and Wilson, R.W. 1975. Analysis of Simimys simplex, an Eocene rodent (?Zapodidae). Journal of Paleontology, 49:856-874.

Lucas, S.G. 1992. Redefinition of the Duchesnean land mammal "age." Late Eocene of western North America, p. 88-105. In Prothero, D.R. and Berggren, W.A. (eds.), Eocene-Oligocene Climatic and Biotic Evolution. Princeton University Press, Princeton.

Lucas, S.G. 2006. A new amynodontid (Mammalia, Perissodactyla) from the Eocene Clarno Formation, Oregon, and its biochronological significance. PaleoBios, 26(2):7-20.
Lucas, S.G., Foss, S.G., and Mihlbachler, M.C. 2004. Achaenodon (Mammalia, Artiodactyla) from the Eocene Clarno Formation, Oregon, and the age of the Hancock Quarry Local fauna, p. 89-95. In Lucas, S.G., Zeigler, K.E., and Kondrashov, P.E. (eds.), Paleogene Mammals. New Mexico Museum of Natural History and Science Bulletin 26.

Manchester, S.R. 1994. Fruits and seeds of the middle Eocene Nut Beds flora, Clarno Formation, Oregon. Palaeontographica Americana, 58:1-205.

Manchester, S.R. 2000. Late Eocene fossil plants of the John Day Formation, Wheeler County, Oregon. Oregon Geology, 62:51-63.

Manchester, S.R. and Mclntosh, W.C. 2007. Late Eocene silicified fruits and seeds from the John Day Formation near Post, Oregon. PaleoBios, 27:7-17.

Matthew, W.D. 1910.On the osteology and relationships of Paramys, and the affinities of the Ischyromyidae. Bulletin of the American Museum of Natural History, 28:43-72.

McClaughry, J.D., Ferns, M.L, Streck, M.J., Patridge, K.A., and Gordon, C.L. 2009. Paleogene calderas of central and eastern Oregon: eruptive sources of widespread tuffs in the John Day and Clarno Formations, p. 407-434. In O'Connor, J.E., Dorsey, R.J., and Madin, I.P. (eds.), Volcanoes to Vineyards: Geologic Field Trips through the Dynamic Landscape of the Pacific Northwest. Geological Society of America Field Guide 15.

McKee, T.M. 1970. Preliminary report on fossil fruits and seeds from the mammal quarry of the Clarno Formation, Oregon. Oregon Department of Geology and Mineral Industries, Ore Bin, 32:117-132.

McKenna, M.C. and Bell, S.K. 1997. Classification of Mammals above the Species Level. Columbia University Press, New York.

Meyer, H.W. and Manchester, S.R. 1997. The Oligocene Bridge Creek flora of the John Day Formation, Oregon. University of California Publications in Geological Sciences, 141:1-195.

Mihlbachler, M.C. 2007. Eubrontotherium clarnoensis, a new genus and species of brontothere (Brontotheriidae, Perissodactyla) from the Hancock Quarry, Clarno Formation, Wheeler County, Oregon. Paleobios, 21:19-39.

Mihlbachler, M.C. and Samuels, J.X. 2016. A small-bodied species of Brontotheriidae from the Middle Eocene Nut Beds of the Clarno Formation, John Day Basin, Oregon. Journal of Paleontology, 90(6):12331244.

Myers, J.A. 2003. Terrestrial Eocene-Oligocene vegetation and climate in the Pacific Northwest, p. 171-185. In Prothero, D.R., Ivany, L.C., and Nesbitt, E.A. (eds.), From Greenhouse to Icehouse, the Marine Eocene-Oligocene Transition. Columbia University Press, New York.

Naylor, B.G. 1979. A new species of Taricha (Caudata: Salamandridae), from the Oligocene John Day For- 
mation of Oregon. Canadian Journal of Earth Sciences, 16:970-973.

Noblett, J.B. 1981. Subduction-related origin of the volcanic rocks of the Eocene Clarno Formation near Cherry Creek, Oregon. Oregon Geology, 43:91-99.

Peck, D.L. 1964. Geologic reconnaissance of the Antelope-Ashwood area of north-central Oregon, with emphasis on the John Day Formation of late Oligocene and early Miocene age. U.S. Geological Survey Bulletin, 1161-D:1-26.

Pratt, J.A. 1988. Paleoenvironment of the Eocene/Oligocene Hancock Mammal Quarry, Upper Clarno Formation, Oregon. Unpublished Master of Science Thesis, University of Oregon, Eugene, Oregon, USA.

Radinsky, L.B. 1963. Origin and Early Evolution of North American Tapiroidea. Peabody Museum of Natural History Bulletin, 17:1-118.

Rensberger, J.M. 1975. Haplomys and its bearing of the origin of the aplodontoid rodents. Journal of Mammalogy, 56:1-14.

Retallack, G.J. 2007. Cenozoic paleoclimate on land in North America. The Journal of Geology, 115:271294.

Retallack, G.J, Bestland, E.A., and Fremd, T.J. 1996. Reconstructions of Eocene and Oligocene plants and animals in central Oregon. Oregon Geology, 58:5169.

Retallack, G.J, Bestland, E.A., and Fremd, T.J. 2000. Eocene and Oligocene paleosols of central Oregon. Geological Society of America Special Paper, 344:1196.

Robinson, P.T. 1975. Reconnaissance geologic map of the John Day Formation in the southwestern part of the Blue Mountains and adjacent areas, north-central Oregon. US Geological Survey Miscellaneous Investigations Map I-872 (scale 1:125,000).

Robinson, P.T., Brem, G.F., and McKee, E.H. 1984. John Day Formation of Oregon: A distal record of early Cascade volcanism. Geology, 12:229-232.

Robinson, P.T., Gunnell, G.F., Walsh, S.L., Clyde, W.C., Storer, J.E., Stucky, R.K., Froelich, D.J., FerrusquiaVillafranca, I., and McKenna, M.C. 2004. Wasatchian through Duchesnean Biochronology, p. 106-155. In Woodburne, M.O. (ed.), Late Cretaceous and Cenozoic Mammals of North America. Columbia University Press, New York.

Russell, L.S. 1972. Tertiary Mammals of Saskatchewan. Part II: The Oligocene Fauna, Non-Ungulate Orders. Life Science Contribution, Royal Ontario Museum, 84:1-108

Simpson, G.G. 1941. A giant rodent from the Oligocene of South Dakota. American Museum Novitates, 1149:1-16.

Storer, J.E. 1988. The rodents of the Lac Pelletier lower fauna, late Eocene (Duchesnean) of Saskatchewan. Journal of Vertebrate Paleontology, 8:84-101.

Sutton, J.F. and Black, C.C. 1975. Paleontology of the earliest Oligocene deposits in Jackson Hole Wyo- ming. Part 1. Rodents exclusive of the family Eomyidae. Annals of Carnegie Museum, 45:299-315.

Swanson, D.A. 1969. Reconnaissance geologic map of the east half of Bend quadrangle, Crook, Wheeler, Jefferson, Wasco, and Deschutes Counties, Oregon. US Geological Survey Miscellaneous Investigations Map I-568 (scale 1:125,000).

Swanson, D.A. and Robinson, P.T. 1968. Base of the John Day Formation in and near the Horse Heaven mining district, north-central Oregon. US Geological Survey Professional Paper, 600-D:154-161.

Swisher, C.C. III. 1992. ${ }^{40} \mathrm{Ar} /{ }^{39} \mathrm{Ar}$ dating and its application to the calibration of the North American Land Mammal ages. Ph.D. dissertation, University of California, Berkeley.

Vianey-Liaud, M., Gomes, J.G., and Marivaux, L. 2013. Early adaptive radiations of Aplodontoidea (Rodenta, Mammalia) on the Holarctic region: systematic and phylogenetic paleobiogeograhic implications. Paläontologische Zeitschrift, 87:83-120.

Walsh, S.L. 2010. New myomorph rodents from the Eocene of Southern California. Journal of Vertebrate Paleontology, 30:1610-1621.

Walsh, S.L. and Gutzler, R.Q. 1999. Late Duchesneanearly Chadronian mammals from the upper member of the Pomerado Conglomerate, San Diego, California. Journal of Vertebrate Paleontology ,19(3, Supplement):82A.

Wheeler, E.A. and Manchester, S.R. 2002. Woods of the Eocene Nut Beds flora, Clarno Formation, Oregon, USA. International Association of Wood Anatomists Journal Supplement 3.

Wheeler, E.A., Manchester, S.R., and Wiemann, M. 2006. Eocene woods of central Oregon. PaleoBios 26(3):1-6.

White, J.D.L. and Robinson, P.T. 1992. Intra-arc sedimentation in a low-lying marginal arc, Eocene Clarno Formation, central Oregon. Sedimentary Geology, 80:89-114.

Wilson, R.W. 1935. Cricetine-like rodents from the Sespe Eocene of California. Proceedings of the National Academy of Sciences, 21:26-32.

Wood, A.E. 1937. The mammalian fauna of the White River Oligocene. Part II. Rodentia. Transactions of the American Philosophical Society, 28:155-269.

Wood, A.E. 1955. A revised classification of the rodents. Journal of Mammalogy, 36:165-187.

Wood, A.E. 1962. The early Tertiary rodents of the family Paramyidae. Transactions of the American Philosophical Society, 52:1-261.

Wood, A.E. 1974. Early Tertiary vertebrate faunas, Vieja Group, Trans-Pecos Texas: Rodentia. Bulletin of the Texas Memorial Museum, 21:1-112.

Wood, A.E. 1976. The Oligocene rodents Ischyromys and Titanotheriomys and the content of the family Ischyromyidae, p. 244-277. In Churcher, C.S. (ed.), Athlon: Essays on Paleontology in Honour of L.S. Russell. University of Toronto Press, Toronto, Ontario. 
Wood, A.E. 1980. The Oligocene rodents of North America. Transactions of the American Philosophical Society, 70:1-68.
Wood, A.E. and Wilson, R.W. 1936. A suggested nomenclature for the cusps of the cheek teeth of rodents. Journal of Paleontology, 10:388-391. 